\title{
Adrenal insufficiency in the preterm infant
}

\author{
Simonetta Picone*, Roberto Aufieri, Piermichele Paolillo \\ From XXI Congress of the Italian Society of Neonatology \\ Palermo, Italy. 24-26 September 2015
}

Cortisol production by the human fetal adrenal cortex has been shown to be not adequate at early gestation. This is due to an inefficient expression of $3 \beta$-hydroxysteroid dehydrogenase, the enzyme that catalyzes the synthesis of progesterone from pregnenolone, before about 23 weeks of gestation. Whereas, the fetal adrenal cortex it is able to produce dehydroepiandrosterone sulphate for placental estrogen synthesis and to convert placental progesterone to cortisol $[1,2]$.

During the last trimester of pregnancy the fetal adrenal gland undergoes significant anatomical and functional maturation for adaptation to extra-uterine life and cortisol production increases greatly in the last two months of gestation. Cortisol increases synthesis of surfactant, enhances the reabsorption of lung fluid, promotes the conversion of $\mathrm{T} 4$ to $\mathrm{T} 3$, favors the closure of the ductus arteriosus and maturation of liver and intestinal enzymes [2].

Adrenal insufficiency can be caused by rare conditions such as adrenocortical hypoplasia or congenital enzymatic deficiencies of steroidogenesis, with clinical variables depending on the hormone involved.

In preterm infants, the developmental immaturity, combined with increased demands in critical illness, may result in insufficient cortisol production to maintain homeostasis in the face of acute stress or illness, despite apparently normal cortisol levels. This condition is known as "transient or relative adrenal insufficiency" (TAI) $[3,4]$.

TAI usually appears in the first week of life and normalizes in the second week. Infants with TAI can exhibit refractory hypotension (hypotension not responsive to volume expanders and inotropic drugs, but responsive to corticosteroids), respiratory distress, patent ductus arteriosus and bronchopulmonary dysplasia (BPD) [2,3]. Diagnosis of TAI is not easy because many other conditions

\footnotetext{
* Correspondence: simpico@libero.it

Division of Neonatology and Neonatal Intensive Care, Casilino General
} Hospital, Roma, Italy

can cause hypotension in VLBW infants: hypovolemia, myocardial dysfunction, deficient vascular tone, hyaline membrane disease, infection or a combinations of these factors. In addition, normal basal cortisol levels are extremely variable in preterms and to date there is no consensus on the diagnosis of adrenal insufficiency based on tests with adrenocorticotropic hormone (ACTH) [5-8]. Appropriate dose and duration of steroid therapy have not been established yet. On the other hand refractory and persistent hypotension is associated with intraventricular hemorrhage, periventricular leukomalacia, increased mortality and neurological disability [9]. Poor adrenal response has been shown to be associated with later development of BPD and with death $[10,11]$.

For these reasons further studies are needed to evaluate the efficacy and safety of glucocorticoids in the treatment of cardiovascular failure due to TAI in ill preterm and term infants $[12,13]$.

\section{Published: 24 September 2015}

References

Watterberg KL: Adrenocortical function and dysfunction in the fetus and neonate. Semin Neonatol 2004, 9:13-21.

2. Chung HR: Adrenal and thyroid function in the fetus and preterm infant. Korean J Pediatr 2014, 57:425-33.

3. Fernandez EF, Watterberg KL: Relative adrenal insufficiency in the preterm and term infant. J Perinatol 2009, 29(Suppl 2):S 44-9.

4. Ng PC, Lee CH, Lam CW, Ma KC, Fok TF, Chan IH, Wong E: Transient adrenocortical insufficiency of prematurity and systemic hypotension in very low birthweight infants. Arch Dis Child Fetal Neonatal Ed 2004, 89:F 119-26.

5. Hochwald O, Holsti L, Osiovich H: The use of an early ACTH test to identify hypoadrenalism-related hypotension in low birth weight infants. J Perinatol 2012, 32:412-7.

6. Greaves RF, Zacharin MR, Donath SM, Inder TE, Doyle LW, Hunt RW: Establishment of hormone reference intervals for infants born $<30$ weeks'gestation. Clin Biochem 2014, 47:101-8.

7. Nykänen P, Heinonen K, Riepe FG, Sippell WG, Voutilainen R: Serum concentrations of adrenal steroids and their precursors as a measure of maturity of adrenocortical function in very premature newborns. Horm Res Paediatr 2010, 74:358-64.

8. Fernandez EF, Montman R, Watterberg KL: ACTH and cortisol response to critical illness in term and late preterm newborns. J Perinatol 2008, 28:797-802. 
9. Dasgupta SJ, Gill AB: Hypotension in the very low birthweight infant: the old, the new, and the uncertain. Arch Dis Child Fetal Neonatal Ed 2003, 88: F 450-4.

10. Watterberg KL, Gerdes JS, Cook KL: Impaired glucocorticoid synthesis in premature infants developing chronic lung disease. Pediatric Res 2001, 50:190-5.

11. Watterberg KL, Gerdes JS, Cole CH, Aucott SW, Thilo EH, Mammel MC, Couser RJ, Garland JS, Rozycki HJ, Leach CL, Backstrom C, Shaffer ML: Prophylaxis of early adrenal insufficiency to prevent bronchopulmonary dysplasia: a multicenter trial. Pediatrics 2004, 114:1649-57.

12. Ng PC, Lee CH, Bnur FL, Chan IH, Lee AW, Wong E, Chan HB, Lam CW, Lee BS, Fok TF: A double-blind, randomized, controlled study of a stress dose of hydrocortisone for rescue treatment of refractory hypotension in preterm infants. Pediatrics 2006, 117:367-75.

13. Bonsante F, Latorre G, lacobelli S, Forziati V, Laforgia N, Esposito L, Mautone A: Early low dose hydrocostisone in very preterm infants: a randomized, placebo-controlled trial. Neonatology 2007, 91:217-21.

doi:10.1186/1824-7288-41-S1-A30

Cite this article as: Picone et al:: Adrenal insufficiency in the preterm infant. Italian Journal of Pediatrics 2015 41(Suppl 1):A30.

\section{Submit your next manuscript to BioMed Central} and take full advantage of:

- Convenient online submission

- Thorough peer review

- No space constraints or color figure charges

- Immediate publication on acceptance

- Inclusion in PubMed, CAS, Scopus and Google Scholar

- Research which is freely available for redistribution

Submit your manuscript at www.biomedcentral.com/submit 